\title{
Heat tolerance in groundnut
}

\author{
P.Q. Craufurd ${ }^{\mathrm{a}, *}$, P.V.V. Prasad ${ }^{\mathrm{a}, 1}$, V.G. Kakani ${ }^{\mathrm{a}, 2}$, \\ T.R. Wheeler ${ }^{\mathrm{a}}$, S.N. Nigam ${ }^{\mathrm{b}}$ \\ ${ }^{a}$ Plant Environment Laboratory, Department of Agriculture, The University of Reading, Cutbush Lane, \\ Shinfield, Reading RG2 9AD, UK \\ ${ }^{\mathrm{b}}$ International Crops Research Institute for the Semi-Arid Tropics, Patancheru P.O., \\ Andhra Pradesh 502324, India
}

Received 29 May 2002; received in revised form 9 August 2002; accepted 16 August 2002

\begin{abstract}
Tolerance to high soil and air temperature during the reproductive phase is an important component of adaptation to arid and semi-arid cropping environments in groundnut. Between 10 and 22 genotypes were screened for tolerance to high air and soil temperature in controlled environments. To assess tolerance to high soil temperature, 10 genotypes were grown from start of podding to harvest at ambient $\left(28^{\circ} \mathrm{C}\right)$ and high $\left(38^{\circ} \mathrm{C}\right)$ soil temperatures, and crop growth rate (CGR), pod growth rate (PGR) and partitioning (ratio PGR:CGR) measured. To assess tolerance to high air temperature during two key stages-microsporogenesis (3-6 days before flowering, DBF) and flowering, fruit-set was measured in two experiments. In the first experiment, 12 genotypes were exposed to short (3-6 days) episodes of high $\left(38^{\circ} \mathrm{C}\right)$ day air temperature at $6 \mathrm{DBF}$ and at flowering. In the second experiment, 22 genotypes were exposed to $40{ }^{\circ} \mathrm{C}$ day air temperature for 1 day at $6 \mathrm{DBF}, 3 \mathrm{DBF}$ or at flowering. Cellular membrane thermostability (relative injury, RI) was also measured in these 22 genotypes. There was considerable variation among genotypes in response to high temperature, whether assessed by growth rates, fruit-set or RI. Pod weight at high soil temperature was associated with variation in CGR rather than partitioning. Flowering was more sensitive to high air temperature than microsporogenesis. Genotypes tolerant to high air temperature at microsporogenesis were not necessarily tolerant at flowering, and nor was tolerance correlated with RI. Six genotypes (796, 55-437, ICG 1236, ICGV 86021, ICGV 87281 and ICGV 92121) were identified as heat tolerant based on their performance in all tests. These experiments have shown that groundnut genotypes can be easily screened for reproductive tolerance to high air and soil temperature and that several sources of heat tolerance are available in groundnut germplasm.

(C) 2003 Elsevier Science B.V. All rights reserved.
\end{abstract}

Keywords: Groundnut; Peanut; Heat tolerance; Temperature; Fruit-set; Membrane thermostability

Abbreviations: DAS, days after sowing; DBF, days before flowering; DAF, days after flowering; CGR, crop growth rate; PGR, pod growth rate; $\mathrm{PF}$, partitioning factor; RI, relative injury

* Corresponding author. Tel.: +44-118-988-3000; fax: +44-118-988-5491.

E-mail address: p.q.craufurd@reading.ac.uk (P.Q. Craufurd).

${ }^{1}$ Present address: Department of Agronomy, University of Florida, Gainesville, FL 32611, USA.

${ }^{2}$ Present address: Department of Plant and Soil Science, Mississippi State University, Mississippi State, MS 39762, USA.

\section{Introduction}

Groundnuts (Arachis hypogaea L.) are an important oilseed, confectionery and livestock feed, particularly for small-scale farmers in semi-arid regions of India and Africa (FAO, 2001). In these semi-arid regions water and high temperature stresses are serious constraints (ICRISAT, 1994). Predicted increases in 
mean temperature of $1.5-6{ }^{\circ} \mathrm{C}$ in future climates (Houghton et al., 2001), as well as an increase in the variability of temperature, will exacerbate these problems (Wheeler et al., 2000). In groundnut, as well as other major staple crops such as rice (Oryza sativa L.; Matthews et al., 1995), heat tolerant genotypes will be needed to sustain production in these environments.

Photosynthesis (Bhagsari et al., 1976; Talwar et al., 1999) and vegetative growth (Prasad et al., 2000a) are well adapted to high temperature in groundnut, and the optimum mean diurnal temperature for these processes is between 30 and $35^{\circ} \mathrm{C}$ (Williams and Boote, 1995). In contrast, reproductive processes in groundnuts are extremely sensitive to high air temperature (Prasad et al., 1999a, 2001), in common with other legumes such as common bean (Phaseolus vulgaris L.) (Gross and Kigel, 1994) and cowpea (Vigna unguiculata L. (Walp.)) (Hall, 1992), and cereals such as rice (Yoshida et al., 1981). In species such as cowpea, common bean and groundnut, two stages of floral development-microsporogenesis and anthesis, are acutely sensitive to high temperature (Hall, 1992; Gross and Kigel, 1994; Prasad et al., 2001). For example, flower buds and open flowers of groundnut genotype ICGV 86015 exposed to air temperatures of 33 and $40{ }^{\circ} \mathrm{C}$ for $12 \mathrm{~h}$ set fruit only in 60 and $10 \%$ of flowers, respectively, compared to plants exposed to $28{ }^{\circ} \mathrm{C}$ (Prasad et al., 2001). Sources of heat tolerance will therefore need to be identified for both these critical stages.

In groundnut, pods and kernels develop and grow underground and therefore tolerance to high soil temperature during pod growth, as well as high air temperature during floral development, is required. The optimum temperature for pod and kernel yield is about $23{ }^{\circ} \mathrm{C}$ (Cox, 1979), well below that for vegetative growth and development. High soil temperature $\left(38{ }^{\circ} \mathrm{C}\right)$ reduces dry matter accumulation, flower production, the proportion of pegs forming pods, and individual seed mass (Golombek and Johansen, 1997; Prasad et al., 2000a).

Cellular membrane thermostability has been suggested as a simple screening technique for heat tolerance in plants (Martineau et al., 1979) and genetic variability for this trait has been identified in a number of crops. In cowpea, for example, pairs of near isogenic lines for reproductive heat toler- ance and susceptibility could be distinguished in growth chamber and field environments based on their membrane thermostability score (Ismail and Hall, 1999). Genotypic differences in membrane thermostability have also been detected in groundnut (Srinivasan et al., 1996; Chauhan and Senboku, 1997).

Genotypes within several crop species are known to differ in heat resistance, where heat resistant cultivars are defined as maintaining or having higher yields at high temperature tolerance (Hall, 1992; Mahan et al., 1995). Heat tolerance, defined as the ability to maintain essential plant functions when tissues become hot (Hall, 1992), is a major component of heat resistance. Genotypic differences in tolerance/susceptibility have been reported in groundnut for partitioning of dry matter to pods and kernels (Greenberg et al., 1992; Wheeler et al., 1997; Ntare et al., 2001; Craufurd et al., 2002), fruit-set (Talwar et al., 1999), and membrane thermostability and chlorophyll fluorescence (Srinivasan et al., 1996; Chauhan and Senboku, 1997). However, with the exception of Greenberg et al. (1992) and Ntare et al. (2001), only a very limited number of genotypes of groundnut have been studied. Furthermore, associations between heat tolerance at different stages of development and heat tolerance assessed by growth and yield, fruit-set and membrane thermostability have not been investigated in groundnut.

The objective of this research was to identify groundnut genotypes tolerant to (a) high soil temperature during pod and kernel growth, (b) high air temperature at microsporogenesis, (c) high air temperature at anthesis, and (d) to determine whether genotypic differences in tolerance to high temperature were associated with membrane thermostability.

\section{Materials and methods}

This research was conducted between July and September in 1998 and 1999 using the controlled environment facilities of the Plant Environment Laboratory, Department of Agriculture, The University of Reading $\left(51^{\circ} 27^{\prime} \mathrm{N}\right.$ latitude and $00^{\circ} 56^{\prime} \mathrm{W}$ longitude), United Kingdom. Experiments were carried out in a polyethylene-covered tunnel structure (polytunnel) and in modified Saxcil growth cabinets. 


\subsection{Polytunnel}

The polytunnel ( $25 \mathrm{~m}$ long by $8 \mathrm{~m}$ wide by $3 \mathrm{~m}$ high at the apex) was naturally lit and aligned east-west. The photo- and thermo-period in the polytunnel was coincident and equal at $12 \mathrm{~h}$ per day. The photo-period was controlled by a manually operated blackout facility. Heating and venting of air controlled day and night temperatures. The polytunnel had an $88 \mathrm{~kW} \mathrm{~h}$ capacity heater which blows air down both sides of each tunnel through $0.3 \mathrm{~m}$ diameter plastic ducts with holes approximately every $0.2 \mathrm{~m}$. Air was continually circulated within the polytunnel. In the roof of the polytunnel were three polythene ducts connected to three fans for venting. The venting fans were switched on in two stages (to avoid dropping the temperature too rapidly) and created a partial vacuum in the polythene ducts, causing air to be sucked into the ducts at the opposite end of the polytunnel. An aspirated and shielded thermocouple mounted at $1.5 \mathrm{~m}$ height in the centre of each polytunnel and connected to a solid-state controller (Nobel Engineering, Bognor Regis) was used to control temperature by adding or losing (by venting) heat. Air temperatures were measured in three positions along the polytunnel using screened and aspirated copper-constantan thermocouples positioned $0.3 \mathrm{~m}$ above the plant canopy. Floral bud temperatures were also measured by inserting $0.2 \mathrm{~mm}$ diameter copper-constantan thermocouples into four randomly selected $5 \mathrm{~mm}$ long floral buds in each temperature regime. Readings were taken at $10 \mathrm{~s}$ intervals and means were stored for successive 10 min periods using data loggers (Delta-T Devices, Cambridge, UK; Campbell Scientific, Shepshed, UK). Carbon dioxide concentration was not controlled but was assumed to be at ambient concentration due to venting and natural leakage into the polytunnel. Relative humidity during the day was maintained close to $70( \pm 5) \%$ using water sprinklers and ventilation. The polytunnel transmitted $73 \%$ of incoming photosynthetically active radiation and photosynthetic photon flux density (PPFD) averaged between 580 and $600 \mu \mathrm{mol} \mathrm{m}{ }^{-2} \mathrm{~s}^{-1}$ across different experiments.

Within the polytunnel, facilities were constructed to impose high air and soil temperature treatments. High soil temperature was imposed by placing pots on a specially constructed bench fitted with five tubular heaters $(2.5 \mathrm{~m}$ long) with a total wattage of $2.4 \mathrm{~kW}$.
Target daytime soil temperature was controlled by automatically switching the heaters on and off using a data logger (Campbell Scientific, Shepshed, UK) connected to a thermocouple buried at $50 \mathrm{~mm}$ depth. Soil temperature during the night was not controlled and pots were allowed to return to ambient temperature. Soil temperatures during the day and night in both ambient and high soil temperature treatments were recorded by copper-constantan thermocouples also placed at a depth of $50 \mathrm{~mm}$ in the soil. Readings were measured at $10 \mathrm{~s}$ intervals and means were stored for successive $10 \mathrm{~min}$ periods using a data logger. The high air temperature facility comprised a 'bubble' made of $40 \mu$ polythene (95\% transmission of PAR) fitted with a $2.8 \mathrm{~kW}$ heater. The heater was controlled through a data logger (Campbell Scientific, Shepshed, UK) connected to a screened and aspirated sensor (Nobel Engineering, Bognor Regis, UK) positioned $0.3 \mathrm{~m}$ above the plant canopy. The target daytime temperature in the bubble was $40{ }^{\circ} \mathrm{C}$; however, the actual mean daytime temperature achieved was $36.7^{\circ} \mathrm{C}$.

\subsection{Growth cabinets}

Modified Saxcil growth cabinets were also used to impose temperature treatments. The photo- and thermo-period in each growth cabinet was coincident and equal at $12 \mathrm{~h}$ per day. The photo-period was controlled with automatic time switches. Air temperatures were measured using screened and aspirated copper-constantan thermocouples positioned $0.3 \mathrm{~m}$ above the plant canopy. Floral bud temperatures were also measured by inserting $0.2 \mathrm{~mm}$ diameter copperconstantan thermocouples into four randomly selected $5 \mathrm{~mm}$ long floral buds in each growth cabinet. Readings were taken at $10 \mathrm{~s}$ intervals and means were stored for successive $10 \mathrm{~min}$ periods using a data logger (Delta-T Devices, Cambridge, UK; Campbell Scientific, Shepshed, UK). Carbon dioxide concentration $\left(\mathrm{CO}_{2}\right)$ was maintained at ambient concentration, $360 \mu \mathrm{mol} \mathrm{CO} \mathrm{mol}^{-1}$ of air. Vapour pressure deficit in cabinets was maintained at $1.2 \mathrm{kPa}$ in all temperature regimes. This was done either by removing the excess humidity by condensation or adding moisture to air by passing through glycol maintained at a set temperature. The PPFD in each growth cabinet was 650 $\mu \mathrm{mol} \mathrm{m} \mathrm{m}^{-2} \mathrm{~s}^{-1}$ and was obtained from a combination 
of cool white fluorescent tubes and incandescent lamps.

\subsection{Plant husbandry}

Seeds were obtained from ICRISAT Centre located at Patancheru in India. Uniform seeds were either pregerminated before planting or sown into module trays filled with potting compost and transplanted after 4 or 8 days, respectively. Seeds were pre-germinated on moist filter paper in Petri dishes kept in the dark for 2 days at room temperature $\left(25^{\circ} \mathrm{C}\right)$ until radicles emerged. The germinated seeds were then sown, one per 2.51 pot at a depth of $25 \mathrm{~mm}$. The rooting medium comprised sand, gravel, vermiculite and loamless peat compost mixed in proportions of $4: 2: 2: 1$ by volume, respectively. A commercial controlled-released fertiliser $\left(0.15 \mathrm{~kg} \mathrm{~N} \mathrm{~kg}^{-1}, 0.10 \mathrm{~kg} \mathrm{P} \mathrm{kg}^{-1}, 0.12 \mathrm{~kg} \mathrm{~K} \mathrm{~kg}^{-1}\right.$, $0.02 \mathrm{~kg} \mathrm{MgO} \mathrm{kg}^{-1}$ plus trace elements; Osmocote Plus, Scotts UK, UK) was incorporated into the mixture at the manufacturer's recommended rate of $5 \mathrm{~g} \mathrm{l}^{-1}$. Seeds were not inoculated with rhizobia and plants were dependent on inorganic nitrogen. All pots were soaked with tap water and allowed to drain for $24 \mathrm{~h}$ before sowing; thereafter they were irrigated as necessary through an automatic drip irrigation system in the polytunnel or were hand-watered while in the cabinets. There were no disease problems and sporadic pest infestations were controlled by releases of predators Phytoseiulus persimilis Herriot against red spider mite (Tetranychus urticae Koch) and Amblyseius cucumeris Oudemes against thrips (Thrips tabaci, Lindeman).

\subsection{Experiment 1: soil temperature 1998}

This experiment, with 10 genotypes varying in heat tolerance/susceptibility, was carried out in a polytunnel fitted with controlled soil temperature facilities. All the plants were grown at $28 / 22{ }^{\circ} \mathrm{C}$ day/night temperature from sowing till the appearance of the first pod (i.e. when peg tip diameter was twice that of remaining peg) at 45 days after sowing (DAS). From 46 DAS to final harvest at 90 DAS plants were exposed to either ambient soil temperature or a high soil temperature treatment of ambient soil temperature $+10{ }^{\circ} \mathrm{C}$.

At podding and harvest, plants were carefully removed from each pot without damaging the root systems and were separated into roots, leaves, stems (including petioles), pegs and pods. The number of pegs, pods, and seeds per plant were counted. The roots were washed to remove the adhering potting medium. The respective dry weights of roots, leaves, stems, pegs, pods, and kernels were recorded after oven-drying each component at $60{ }^{\circ} \mathrm{C}$ for 4 days.

Total dry matter yield per plant, pod harvest index (i.e. the ratio of pod dry weight to total dry matter yield) and root-to-shoot ratio (i.e. the ratio of root dry weight to total above-ground dry weight) at harvest were calculated from the weights of individual components. Values of pod yields were adjusted by multiplying by a factor of 1.65 to allow for the energy content of oil in the kernels (Duncan et al., 1978). All data are expressed on a per plant basis unless otherwise stated. Crop growth rate (CGR, g per plant per day) and pod growth rate (PGR, g per plant per day) were calculated from total dry weight at the start of podding $\left(t_{1}\right)$ and pod dry weight and total dry weight at harvest $\left(t_{2}\right)$ as

CGR $=\frac{\text { total dry weight at } t_{2}-\text { total dry weight at } t_{1}}{t_{2}-t_{1}}$

PGR $=\frac{\text { pod dry weight at } t_{2}}{t_{2}-t_{1}}$

and the partitioning factor (PF) as

$\mathrm{PF}=\frac{\mathrm{PGR}}{\mathrm{CGR}}$

The experiment was laid out as a split-plot design with soil temperature as main plots and genotypes and replicates as subplots. Ten genotypes varying in heat tolerance were used (Table 1) and each was replicated five times. The main effects of temperature were not replicated. Variances were similar in the high and control soil temperature treatments and therefore a pooled S.E. and $t$-test were used to compare these two treatments. The analysis of variance for all the variables was performed using Genstat 5 (Genstat 5 Committee, 1987).

\subsection{Experiment 2: air temperature 1998}

This experiment with 12 genotypes was carried out in a polytunnel containing a high temperature treatment facility. All plants were grown in the polytunnel 
Table 1

List of genotypes, and their pedigree, origin, ecotype, and drought tolerance (T) or susceptibility (S) used in the three experiments

\begin{tabular}{|c|c|c|c|c|c|c|c|c|}
\hline \multirow[t]{2}{*}{ No. } & \multirow[t]{2}{*}{ Genotype } & \multirow[t]{2}{*}{ Pedigree } & \multirow[t]{2}{*}{ Origin } & \multirow[t]{2}{*}{ Ecotype } & \multirow{2}{*}{$\begin{array}{l}\text { Drought } \\
\text { tolerance }^{\mathrm{a}}\end{array}$} & \multicolumn{3}{|c|}{ Experiment number } \\
\hline & & & & & & 1 & 2 & 3 \\
\hline 1 & ICGV 86015 & ICGS $44 \times$ TG $2 \mathrm{E}$ & India & $\mathrm{SB}^{\mathrm{b}}$ & $-{ }^{c}$ & $\times$ & $x$ & \\
\hline 2 & ICGV 86021 & RMP $91 \times$ DHT 200 & India & SB & - & $\times$ & $\times$ & \\
\hline 3 & ICGS 11 & $\begin{array}{l}\text { Selection from natural } \\
\text { hybrid Robut } 33-1\end{array}$ & India & SB & $\mathrm{S}$ & $\times$ & $\times$ & $\times$ \\
\hline 4 & Kadiri 3 (Robut 33-1) & Selection from Robut 33 & India & $\mathrm{VB}^{\mathrm{d}}$ & $\mathrm{S}$ & $x$ & $x$ & $\times$ \\
\hline 5 & 796 & & & SB & - & $x$ & $\times$ & \\
\hline 6 & TMV 2 & Selection from Gudhiatham Bunch & India & SB & $\mathrm{T}$ & $x$ & $\times$ & $\times$ \\
\hline 7 & $55-437$ & $\begin{array}{l}\text { Selection from a population } \\
\text { of probably South American origin }\end{array}$ & Senegal & SB & $\mathrm{T}$ & $\times$ & $\times$ & $\times$ \\
\hline 8 & ICG 1236 (Ah6179) & & India & SB & $\mathrm{T}$ & $x$ & $\times$ & $\times$ \\
\hline 9 & 28-206 & $\begin{array}{l}\text { Selection from a population } \\
\text { from Mali }\end{array}$ & Senegal & VB & $\mathrm{S}$ & $\times$ & $\times$ & $\times$ \\
\hline 10 & $47-16$ & & Madagascar & VB & $\mathrm{T}$ & $x$ & $\times$ & $\times$ \\
\hline 11 & TS32-1 & Selection from Spantex $\times \mathrm{Te} 3$ & Burkina Faso & SB & - & & $x$ & $\times$ \\
\hline 12 & ICGV 87281 & ICGS $46 \times($ TMV $10 \times$ PI259747 $)$ & India & SB & - & & $x$ & \\
\hline 13 & ICGV 92121 & Ah $7827 \times$ ICGS 11 & India & VB & $\mathrm{T}$ & & & $\times$ \\
\hline 14 & ICGV 93272 & ICGS $11 \times$ Robut 33-1 & India & SB & - & & & $\times$ \\
\hline 15 & ICGV 92113 & ICG $1697 \times$ ICG 4790 & India & SB & $\mathrm{S}$ & & & $\times$ \\
\hline 16 & ICGV 93269 & ICGS $11 \times$ JL 24 & India & SB & $\mathrm{T}$ & & & $\times$ \\
\hline 17 & ICGV 93260 & ICGS $11 \times$ ICG 4728 & India & SB & $\mathrm{T}$ & & & $\times$ \\
\hline 18 & ICGV 92120 & ICG $3736 \times($ TMV $10 \times$ Chico $)$ & India & VB & $\mathrm{T}$ & & & $\times$ \\
\hline 19 & ICGV 92118 & ICGV $87340 \times$ ICGS 11 & India & SB & $\mathrm{S}$ & & & $\times$ \\
\hline 20 & ICG 796 (Punjab 648) & & India & $\mathrm{VR}^{\mathrm{e}}$ & - & & & $\times$ \\
\hline 21 & ICGV 93261 & ICGS $11 \times$ ICG 4728 & India & SB & $\mathrm{T}$ & & & $\times$ \\
\hline 22 & ICGV 92116 & $($ TMV $10 \times$ Chico $) \times$ ICGV 86742 & India & VB & $\mathrm{S}$ & & & $\times$ \\
\hline 23 & ICGV 93255 & ICGS $30 \times$ ICGS 11 & India & SB & - & & & $\times$ \\
\hline 24 & ICGV 93232 & ICGV $87399 \times$ Ah 7827 & India & VB & $\mathrm{S}$ & & & $\times$ \\
\hline 25 & ICGV 92109 & ICGV $87399 \times$ Ah 7827 & India & VB & $\mathrm{S}$ & & & $\times$ \\
\hline 26 & ICGV 93233 & ICGV $87399 \times$ Ah 7827 & India & VB & $\mathrm{S}$ & & & x \\
\hline
\end{tabular}

${ }^{\text {a }}$ J.H. Williams, pers. commun.; S.N. Nigam, unpublished data.

b Spanish bunch.

${ }^{\mathrm{c}}$ No data.

d Virginia bunch.

e Virginia runner.

at $28 / 22{ }^{\circ} \mathrm{C}$ from planting to 6 days before flowering (DBF), to coincide with microsporogenesis (Prasad et al., 1999b, 2001), or to first flowering. At 6 DBF one cohort of four plants (pots) of each genotype was moved into the bubble and kept there for 6 days before being returned to $28 / 22{ }^{\circ} \mathrm{C}$. Similarly, at first flowering another cohort of three plants of each genotype was transferred to the bubble and kept there for 3 days, before returning to $28 / 22{ }^{\circ} \mathrm{C}$. In both the treatments the number of flowers opening each day was recorded between first flowering and 24 days after flowering (DAF). Plants were harvested $24 \mathrm{DAF}$ when pegs from flowers opening during the high temperature treatment had had time to form. Fruit-set was recorded as the ratio of pegs to flowers produced during the 3-day high temperature treatment at first flowering or in the 6 days following the treatment at $6 \mathrm{DBF}$.

Number of flowers and pegs, and fruit-set, in the pre-flowering and flowering high temperature treatments were analysed separately by ANOVA. In each case the design was a split-plot design with unreplicated temperature treatments as main plots and genotypes and replicates as subplots. Variances in the high and control temperature treatments were similar and therefore a pooled S.E. and $t$-test were used to compare the main effects of temperature. 


\subsection{Experiment 3: air temperature 1999}

This experiment was carried out using the polytunnel and growth cabinets following the method of Prasad et al. (2001). All plants were grown in a polytunnel maintained at near optimum day/night temperature of $28 / 22{ }^{\circ} \mathrm{C}$ from planting to $9 \mathrm{DAF}$. Thereafter, five plants of each genotype were transferred to a growth cabinet and exposed to a day/night air temperature regime of $40 / 22{ }^{\circ} \mathrm{C}$ for 1 day. After the 1 day high temperature treatment plants were returned to the polytunnel. Plants transferred to a growth cabinet at $28 / 22{ }^{\circ} \mathrm{C}$ for 1 day acted as controls.

The effect of high temperature on fruit-set at three stages of development-DBF, $3 \mathrm{DBF}$ and at first flowering, was measured by tagging individual flowers and buds using the protocol of Prasad et al. (2001). The effect of high temperature at different stages of floral bud development was determined based on the start of the high temperature treatment and time of flower opening. For example, to determine the effect of high temperature at first flowering, individual flowers that opened during the high temperature treatment in the growth cabinet were tagged. Similarly, the effects of high temperature on the stages of development occurring 3 and 6 DBF were determined by tagging flowers that opened 3 and 6 days, respectively, after the high temperature treatment (i.e. when plants were back in the polytunnel at $28 / 22{ }^{\circ} \mathrm{C}$ ). All untagged flowers before and after the start of the temperature treatments were removed. Fruit-set was estimated as the ratio of number of fruits to total number of flowers tagged. In each treatment a maximum of 25 flower buds or flowers were tagged per genotype. All the plants were harvested 20 days after the completion of the temperature treatments so that all the flowers tagged during the treatments had an opportunity to set fruit and produce a peg. Plants that developed continuously at $28 / 22{ }^{\circ} \mathrm{C}$ served as controls.

In this experiment between 7 and 25 flowers per genotype were tagged in each treatment and the ability of those tagged flowers to form a peg (fruit-set) was estimated to quantify the tolerance to high temperature. There are only two possible outcomes associated with individual tagged flowers-either a flower forms a peg or it does not. Therefore, data were treated as a binomial population and analysed using a linear logistic regression model in SAS (SAS Institute, 1996) with time of treatment (stage of development), temperature, genotype and their interactions as dependent variables (Prasad et al., 2001).

\subsection{Cellular membrane thermostability}

Cellular membrane thermostability of the 22 genotypes used in Experiment 3 was determined using the procedure described by Srinivasan et al. (1996). Fully opened leaflets from the top of the canopy were collected at flowering from six plants of each genotype growing at $28 / 22{ }^{\circ} \mathrm{C}$ in a polytunnel. From each plant 10 leaf discs (20 mm diameter) were cut using a cork borer. Disks were immediately washed three to four times in deionised water to remove electrolytes from injured cells at the cut edge and any surface adhering electrolytes. Each set of 10 discs was then immersed in $30 \mathrm{ml}$ water maintained at $25{ }^{\circ} \mathrm{C}$ in a test tube. The test tubes containing the discs were then given a temperature treatment of $54{ }^{\circ} \mathrm{C}$ for $15 \mathrm{~min}$ in a water bath. A set of control discs was kept at $25^{\circ} \mathrm{C}$. After cooling to room temperature, discs were incubated at $10{ }^{\circ} \mathrm{C}$ for $16 \mathrm{~h}$ and conductivity measured (Fisher Scientific, Pittsburgh, USA). The test tubes were then covered with aluminium foil and autoclaved at $120{ }^{\circ} \mathrm{C}$ for $15 \mathrm{~min}$ to release all electrolytes. After cooling to $25^{\circ} \mathrm{C}$, the contents were mixed and final conductance was measured. The relative injury (RI) was determined as

$\mathrm{RI}(\%)=\left\{\frac{1-\left[1-\left(T_{1} / T_{2}\right)\right]}{\left[1-\left(C_{1} / C_{2}\right)\right]}\right\} \times 100$

where $T$ and $C$ refer to the conductance in the treatment and control tubes, respectively, and the subscripts 1 and 2 the readings before and after autoclaving, respectively. Values of RI were analysed as an RBD with six replicates.

\section{Results and discussion}

\subsection{Experiment 1: soil temperature 1998}

There were significant differences among genotypes for all parameters measured (all at $P<0.001$ ) and significant genotype $\times$ temperature interactions for total dry weight $(P<0.001)$, partitioning to pods $(P<0.05)$, number of pods $(P<0.001)$, and individual pod weight $(P<0.01)$. 
Table 2

Effect of ambient (mean day temperature $28^{\circ} \mathrm{C}$ ) and high (mean $38^{\circ} \mathrm{C}$ ) soil temperature from podding to maturity on dry matter and yield components per plant in peanut (data are means of 10 genotypes and five replicates)

\begin{tabular}{lcll}
\hline Component & $28{ }^{\circ} \mathrm{C}$ & $38{ }^{\circ} \mathrm{C}$ & S.E. \\
\hline Total dry weight $(\mathrm{g})$ & 114.4 & 87.8 & $0.69^{\text {**** }}$ \\
Total no. of pods & 61.5 & 45.7 & $1.74^{* * * *}$ \\
Pod dry weight $(\mathrm{g})$ & 30.9 & 25.0 & $1.04^{\text {*** }}$ \\
Pod HI $(\%)$ & 27 & 29 & 1.6 \\
\hline
\end{tabular}

*** Significant at $P \leq 0.01$ probability level.

*** Significant at $P \leq 0.001$ probability level.

Increasing soil temperature during the day from ambient $\left(28{ }^{\circ} \mathrm{C}\right)$ to high $\left(38{ }^{\circ} \mathrm{C}\right)$ from podding $(45$ DAS) to harvest (90 DAS) reduced dry matter accumulation, and pod numbers and yields, by between 20 and $28 \%$ (Table 2). High soil temperature had no significant effect on root: shoot ratio, which averaged 0.19 . The total number of pegs + pods, and pods, were reduced to a similar extent by high soil temperature. High soil temperature therefore had no effect on the ratio of pegs forming pods, which was 0.64 and 0.59 at ambient and high soil temperature, respectively. The proportion of pods with and without kernels was also similar at ambient and high soil temperature (0.70), as was the shelling percentage (58\%). However, in pods with kernels, kernel size was slightly larger under ambient $(0.37 \mathrm{~g})$ than high temperature $(0.32 \mathrm{~g})$ conditions. High soil temperature therefore reduced total dry matter, number of pods and kernel size, but did not affect number of pegs and pod HI, despite the decrease in the number of pods and kernel size.

These effects of high temperature are similar to those reported by Golombek and Johansen (1997) and Prasad et al. (2000a). Golombek and Johansen (1997), for example, found that a soil temperature of $38 / 32{ }^{\circ} \mathrm{C}$ (day/night) reduced total dry weight and pod dry weight by about $20 \%$ compared with soil temperatures of $32 / 26$ and $26 / 20{ }^{\circ} \mathrm{C}$. Lower pod yields at high soil temperature were attributed to slower pod initiation rates, lower PGRs and smaller kernels.

There were significant differences between genotypes in their response to high soil temperature, and these are illustrated in terms of CGR, PGR and partitioning (PF) of CGR to PGR (Fig. 1). Under ambient conditions CGR varied from 1.28 to $2.72 \mathrm{~g}$ per plant per day and was greater in Virginia (genotypes 4, 9 and 10) than Spanish genotypes. High soil temperature reduced CGR by about $50 \%$ in half the genotypes. CGR in genotypes ICGV 86021 (denoted by ' 2 ' in Fig. 1), 796 (5) and ICG 1236 (8) were not affected by high soil temperature and that of genotypes TMV 2 (6), 55-437 (7) and 47-16 (10) only moderately reduced. PGRs under ambient and high soil temperature conditions varied from 0.35 to 0.83 , and $0.18-0.73 \mathrm{~g}$ per plant per day, respectively. There was no genotype $\times$ temperature interaction for PGR and across genotypes PGR was reduced on average from 0.65 (S.E. 0.057) to 0.52 (S.E. 0.059) g per plant per day.

The proportion of CGR partitioned to PGR also varied among genotypes in response to soil temperature
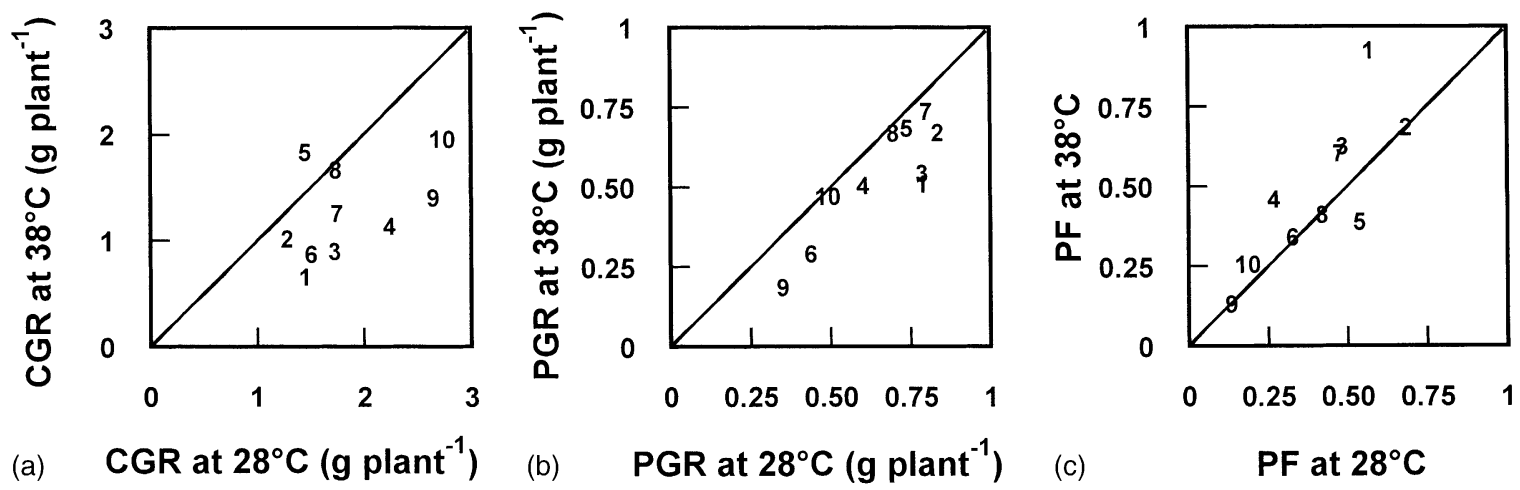

Fig. 1. Relations between (a) CGR, (b) PGR and (c) the PF of 10 genotypes of groundnut grown at ambient $\left(28^{\circ} \mathrm{C}\right)$ and high $\left(38^{\circ} \mathrm{C}\right)$ soil temperature from podding to harvest in Experiment 1 . See Table 1 for key to genotype numbers. 
Table 3

Effect of ambient $\left(28^{\circ} \mathrm{C}\right)$ and high $\left(37^{\circ} \mathrm{C}\right)$ air temperature at microsporogenesis $(0-6 \mathrm{DBF})$ and flowering on the number of flowers produced either during 6 day period immediately after the high temperature treatment at microsporogenesis or during the 3-day high temperature treatment at flowering, and the total number of pegs and pods (RN) and percentage fruit-set of those flowers (data are the mean of 12 genotypes and three $\left(28^{\circ} \mathrm{C}\right)$ or $4\left(37^{\circ} \mathrm{C}\right)$ replicates $)$

\begin{tabular}{|c|c|c|c|c|c|c|c|c|c|}
\hline \multirow[t]{2}{*}{ Stage of development } & \multicolumn{3}{|c|}{ Flower number } & \multicolumn{3}{|l|}{$\mathrm{RN}$} & \multicolumn{3}{|c|}{ Fruit-set $(\%)$} \\
\hline & $28^{\circ} \mathrm{C}$ & $37^{\circ} \mathrm{C}$ & S.E. & $28^{\circ} \mathrm{C}$ & $37^{\circ} \mathrm{C}$ & S.E. & $28{ }^{\circ} \mathrm{C}$ & $37^{\circ} \mathrm{C}$ & S.E. \\
\hline Microsporogenesis & 24.8 & 29.5 & $2.17^{*}$ & 17.0 & 17.4 & 1.78 & 69 & 59 & $4.6^{*}$ \\
\hline Flowering & 10.8 & 12.5 & 1.76 & 7.9 & 7.5 & 1.15 & 73 & 57 & $6.0^{* *}$ \\
\hline
\end{tabular}

* Significant at $P \leq 0.05$ probability level.

** Significant at $P \leq 0.01$ probability level.

(Fig. 1c). The PF under ambient conditions varied from 0.13 in 28-206 to 0.68 in ICGV 86021, and was higher in Spanish than Virginia (genotypes 4, 9 and 10) genotypes. On average, high soil temperature increased PF slightly, from 0.41 (S.E 0.058 ) to 0.48 (S.E. 0.0766). The genotype that recorded the greatest increase in PF by high soil temperature, from 0.57 to 0.92, was ICGV 86015 (1). Genotype 796 (5) was the only genotype where PF was reduced by high temperature, from 0.54 to 0.39 .

Under the conditions used for screening here, namely continuous high daytime soil temperature during pod and kernel development and growth, variation in CGR, rather than PGR or PF, determined tolerance to high soil temperature. The genotypes showing the greatest tolerance to high soil temperature were 796, 55-437, ICG 1236, ICGV 86021 and 47-16. CGR at $28{ }^{\circ} \mathrm{C}$ did not influence susceptibility. Genotypes 796, 55-437 and ICG 1236 have all been shown to have high CGR or high values for PF under Sahelian conditions where air temperatures were $40 / 26^{\circ} \mathrm{C}$ and soil temperatures likely to be greater than $35^{\circ} \mathrm{C}$ (Ntare et al., 2001). However, Golombek and Johansen (1997), who grew genotypes adapted to the Sahel, Indian semi-arid tropics and Canadian prairies, at high soil temperature, found no genotypic variation in response to soil temperature.

Plants in this (and subsequent experiments) were not inoculated with Rhizobium and were dependent on inorganic $\mathrm{N}$. Nodule metabolism and $\mathrm{N}$-fixation are sensitive to heat in groundnut (Kishinevsky et al., 1992). Vara Prasad et al. (2001), who grew ICGV 86015 at high $\left(38 / 22{ }^{\circ} \mathrm{C}\right)$ air and/or soil temperature, observed significant effects of high soil, but not air, temperature on nodule number and dry weight compared with ambient $\left(28 / 22{ }^{\circ} \mathrm{C}\right)$ temperatures. In their study, plants dependent on inorganic $\mathrm{N}$ (100 ppm) had similar pod yields and specific leaf $\mathrm{N}$ at high soil temperature to those inoculated with Rhizobium strain NC92 and given $20 \mathrm{ppm}$ N. However, a combination of high air and soil temperature had a more detrimental effect on plants dependent only on inorganic N. Clearly, interactions between genotype, Rhizobium strain and soil and air temperature may be important and screening for tolerance to high soil temperature should be carried out on nodulated plants with appropriate strains from semi-arid environments.

\subsection{Experiment 2: air temperature 1998}

Twelve genotypes, including 10 grown at high soil temperature, were exposed to high daytime (08:0020:00 h) air temperature (mean of $37^{\circ} \mathrm{C}$ ) at two different stages of development, 0-6 DBF and flowering (Table 3). Flower production varied greatly among genotypes at ambient temperature. In the 6-day period from first flowering between 13 (genotype 47-16) and 39 (genotypes ICGV 86021 and ICGS 11) flowers were produced and peg + pod number $(\mathrm{RN})$ was strongly correlated with flower production $(r=0.96)$. Overall genotypes, high air temperature increased the number of flowers that opened following high temperature at 0-6 DBF (0.78 flowers per day) and during flowering (0.57 flowers per day) but had no effect on RN (Table 3). Fruit-set was decreased by high temperature at both stages of development, from a mean of $71 \%$ at ambient temperature to $58 \%$ at high temperature. In previous studies with some of the same genotypes both increases and reductions in flower production at high temperature have been observed (Prasad et al., 


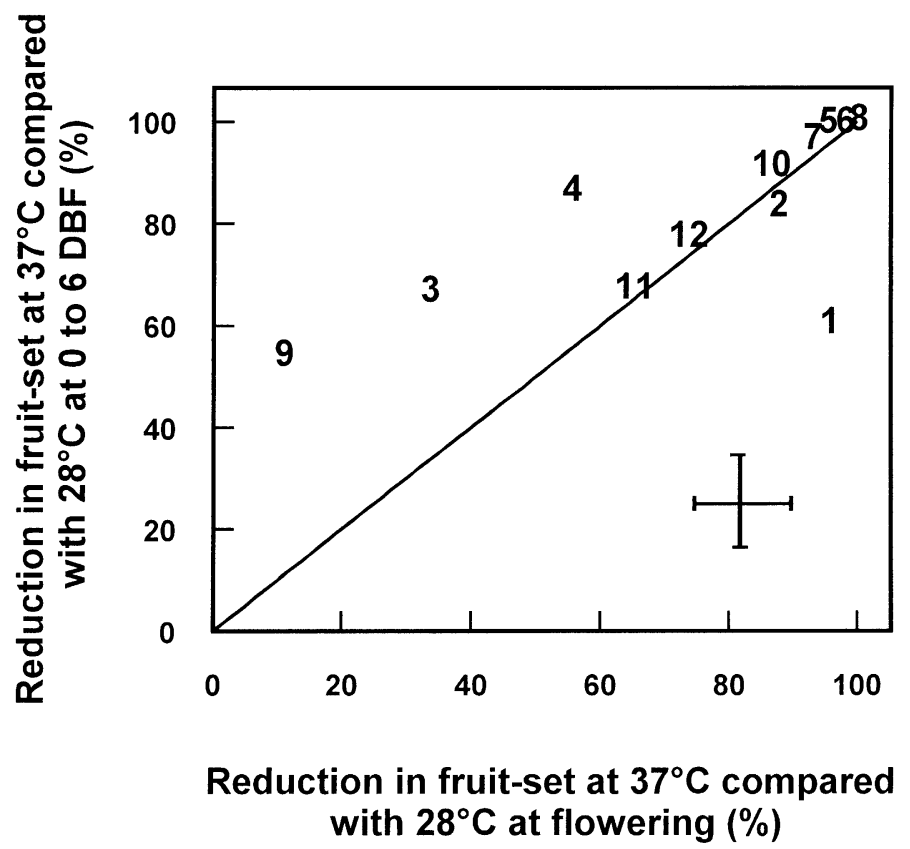

Fig. 2. Relation between the reduction in fruit-set at $37^{\circ} \mathrm{C}$ compared with $28{ }^{\circ} \mathrm{C}$ at $0-6 \mathrm{DBF}$ and at flowering in 12 genotypes of groundnut investigated in Experiment 2. Bars are S.E. of mean. See Table 1 for key to genotype numbers.

1999b, 2000b; Craufurd et al., 2000). However, all the previous studies have found fruit-set to be reduced by high air temperature, and the average reduction here of about $20 \%$ at a daytime temperature of $37^{\circ} \mathrm{C}$ is comparable to that reported for ICGV 86015 under similar conditions by Prasad et al. (2000b).

There were significant differences $(P<0.05)$ between genotypes in the response of fruit-set to high temperature. Most genotypes had mean values of fruitset of 70-80\% at ambient temperature; only genotypes ICGS 11 (62\%), Kadiri $3(52 \%)$ and 28-206 (48\%) had values below $70 \%$. At high temperature, fruit-set varied between 25 and $84 \%$ at $0-6 \mathrm{DBF}$, and 6 and $86 \%$ at flowering. The lowest and the highest absolute values of fruit-set occurred in genotypes 28-206 and TMV 2, respectively. There was no relation between fruit-set at ambient or high temperature and flower production at either stage of development $\left(R^{2}=-0.06\right.$ and -0.10 , respectively).

To examine the effects of high temperature independently of genotypic differences in fruit-set at ambient temperature, fruit-set at high temperature was calculated as the reduction in fruit-set at high $\left(37^{\circ} \mathrm{C}\right)$ compared with ambient $\left(28^{\circ} \mathrm{C}\right)$ temperature.
The relation between the sensitivity of fruit-set to high temperature at $0-6 \mathrm{DBF}$ and flowering is presented in Fig. 2. High temperature at 0-6 DBF reduced fruit-set by $0-45 \%$ compared to ambient temperature. High temperature during the 6 days before first flowering coincides with microsporogenesis and affects pollen production (number) and pollen viability (Prasad et al., 1999a, 2001). The most tolerant genotypes, upon which high temperature had no effect on fruitset, were 796 (denoted by ' 5 ' in Fig. 2), TMV2 (6), 55-437 (7) and ICG 1236 (8). The most susceptible genotype was 28-206 (9).

High temperature at flowering also reduced fruitset, and again there were substantial differences among genotypes. Pollen germination and pollen tube growth are particularly sensitive to high air temperature (Prasad et al., 2001; Kakani et al., in press), and pollen shedding may be adversely affected (Gross and Kigel, 1994; Prasad et al., 1999a). Two genotypes in particular, 28-206 (9) and ICGS 11 (3), were very sensitive to high temperature at flowering and fruit-set was reduced by $>80 \%$ compared to ambient values. In eight genotypes $(2,5-8,10-12)$ with relative values for fruit-set $>60 \%$, the effect of high temperature at 
Table 4

Parameter estimates and their significance from a linear logistic regression model with a binomial distribution of the effects of stage of development, temperature and genotype on fruit-set in 22 genotypes of groundnut

\begin{tabular}{lrl}
\hline Parameter & Estimate & $P$-Value \\
\hline Constant & 1.380 & $\mathrm{~ns}$ \\
Stage of development (S) & 0.638 & $\mathrm{~ns}$ \\
Temperature (T) & -1.478 & $<0.05$ \\
Genotype (G) & 0.089 & $\mathrm{~ns}$ \\
$\mathrm{~S} \times \mathrm{T}$ & -0.039 & $\mathrm{~ns}$ \\
$\mathrm{~S} \times \mathrm{G}$ & -0.078 & $<0.05$ \\
$\mathrm{~T} \times \mathrm{G}$ & -0.057 & $\mathrm{~ns}$ \\
$\mathrm{~S} \times \mathrm{T} \times \mathrm{G}$ & 0.046 & $<0.05$ \\
\hline
\end{tabular}

flowering was similar to that at 0-6 DBF. As a consequence, there was a significant relation $\left(R^{2}=0.49\right.$, $n=12, P<0.05)$ between relative sensitivity to high temperature across both stages of development. However, in three of the genotypes (ICGS 11 (3), Kadiri 3 (4) and 28-206 (9)) flowers were more sensitive than floral buds to high temperature; whereas in genotype ICGV 86015 (1) floral buds were more sensitive to high temperature than flowers. Among the genotypes tested, 796, TMV 2, 55-437 and ICG 1236 were all tolerant of high air temperature at both stages of development. Talwar and Yanagihara (1999) had previously identified ICG 1236 as a heat tolerant genotype in terms of fruit-set at high air temperature.

\subsection{Experiment 3: air temperature 1999}

High air temperature treatments in 1999 were imposed by placing plants in growth cabinets for 1 day at a daytime temperature of $40{ }^{\circ} \mathrm{C}$. Fruit-set in 1999 was analysed with individual tagged flowers as replicates using a regression model with binomial proportions (Prasad et al., 2001). The regression analysis showed significant effects of temperature, genotype $\times$ stage of development, and temperature $\times$ genotype $\times$ stage of development interactions (Table 4 ). High air temperature had relatively little effect on fruit-set at $6 \mathrm{DBF}$ compared to $3 \mathrm{DBF}$ and flowering, and data from this treatment is not presented.

The average number of flower buds tagged at $3 \mathrm{DBF}$ was 14.5 (range: 7-25) in the ambient control and 16.0 (range: 7-28) in the high temperature treatment. Fruit-set under ambient conditions averaged 69\%

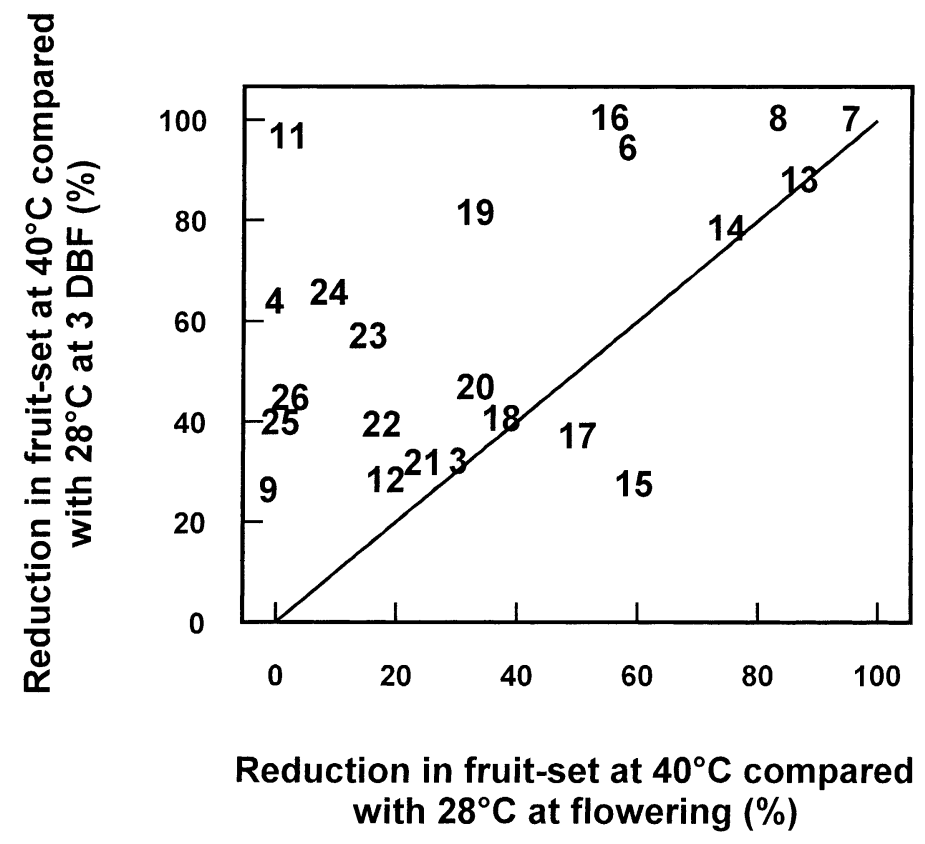

Fig. 3. Relation between the reduction in fruit-set at $40{ }^{\circ} \mathrm{C}$ compared with $28{ }^{\circ} \mathrm{C}$ at $3 \mathrm{DBF}$ and at flowering in 22 genotypes of groundnut investigated in Experiment 3. See Table 1 for key to genotype numbers. 
(S.E. 3.31), and most genotypes had values between 60 and $75 \%$, similar to 1998 . The lowest fruit-set recorded, 33\%, was in genotype ICGV 92109. Average fruit-set at high temperature was $43 \%$ (range: 14 90 ), slightly lower than the value of $52 \%$ observed at a similar stage of development in 1998. Given that the mean daytime temperature was $37.6{ }^{\circ} \mathrm{C}$ in $1998 \mathrm{com}$ pared with $40{ }^{\circ} \mathrm{C}$ in 1999 , this difference was to be expected (Prasad et al., 2001).

Genotypic values for fruit-set at high temperature compared with values under ambient conditions ranged from 26 to $100 \%$, and are illustrated in Fig. 3. Eight genotypes (nos. 5, 6-8, 13, 14, 16 and 19) had values for fruit-set of $>75 \%$ of ambient values, and could therefore be classed as tolerant to high temperature at $3 \mathrm{DBF}$, i.e. at microsporogenesis. The tolerant genotypes included 55-437 (7) and ICG 1236 (8). In contrast, in 11 genotypes fruit-set was reduced $>50 \%$ by high temperature. Included in this group were genotypes 28-206 (9), 47-16 (10) and ICGS 11 (3).

The average number of flowers tagged at flowering was 7.7 (range: 3-20) at ambient temperature and 8.3 (range: 3-16) at high temperature. Fruit-set at ambient temperature averaged $62 \%$ (S.E. 2.1) and values ranged from 50 to $83 \%$. Plants were more susceptible to high temperature at flowering than at $3 \mathrm{DBF}$, as they were in 1998, and average fruit-set was reduced to $23 \%$. A number of genotypes set no fruits at all.

Genotypic tolerance of fruit-set to high temperature, compared with fruit-set at ambient temperature, again varied greatly (Fig. 3). Three genotypes, 55-437 (7), ICG 1236 (8) and ICGV 929121 (13) were tolerant to high temperature at flowering with values for fruitset of $>75 \%$ of the ambient control. In contrast, 10 genotypes were highly susceptible to high temperature at flowering with values of fruit-set of $<25 \%$ of the control. This group included five genotypes (Kadiri 3 (4), TS32-1 (11), 28-206 (9), ICGV 92109 (25) and ICGV 93233 (26)) that set no fruits at high temperature.

There was only a weak relationship between fruitset at $3 \mathrm{DBF}$ and flowering $\left(R^{2}=0.28, n=22\right.$, $P<0.01)$ and genotypes were generally more susceptible to high temperature at flowering than at 3 DBF. However, four genotypes, namely 55-437 (7), ICG 1236 (8) ICGV 92121 (13) and ICGV 93272 (14) were tolerant to high temperature at $3 \mathrm{DBF}$ and flowering. Other genotypes exhibited tolerance at one stage of development only. For example, TS321 (11) was highly tolerant of high temperature at 3 DBF but highly susceptible at flowering. In contrast, ICGV 92113 (15) had some tolerance to high temperature at flowering, but was susceptible at $3 \mathrm{DBF}$. Lastly, genotypes such as 28-206 (9), 47-16 (10), ICGS 11 (3) and ICGV 92116 (21) were highly susceptible to high temperature at both $3 \mathrm{DBF}$ and flowering.

From the results of Experiments 1 and 2 it is apparent that sensitivity to high air temperature in groundnut was different at microsporogenesis, which occurs between 0 and $6 \mathrm{DBF}$, and flowering, and that different genes or alleles confer tolerance at these two stages of development. This is the case in cowpea, where a single dominant gene confers heat tolerance at flowering and two recessive genes confer heat tolerance during microsporogenesis (Hall, 1992). Previous studies in cowpea (Hall, 1992, 1993), common bean (Gross and Kigel, 1994) and groundnut (Prasad et al., 1999a) have shown that heat during microsporogenesis and flowering affects different processes during pollen development and fertilisation.

\subsection{Comparison across 1998 and 1999}

Eight genotypes were common to both high air temperature-screening experiments in 1998 and 1999 (Table 1). A visual comparison of Figs. 2 and 3 shows very clearly that while genotypes TMV 2 (6), 55-437 (7) and ICG 1236 (8) were tolerant to high temperature at both microsporogenesis (0-6 DBF) and flowering in 1998 and 1999, and genotype 28-206 (9) susceptible to high temperature in both the years, genotypes such as 47-16 (10) and TS32-1 (11) were tolerant in 1998 but susceptible in 1999 at one or both stages. The values for Kendall's coefficient of rank correlation for fruit-set at microsporogenesis and flowering in 1998 and 1999 (with 8 d.f.) were 0.50 (ns) and $0.54(P<0.05)$, respectively, indicating a weak association across both years at flowering. However, the sample size is too small to draw any firm conclusion.

Mean daytime temperature during screening (37.6 and $40{ }^{\circ} \mathrm{C}$ ), as well as the duration of exposure to high temperature (1-6 days) also varied between 1998 and 1999. It is possible that the quantitative response to 
Table 5

Membrane thermostability score (RI) and ratio of high to optimum temperature responses of CGR to soil temperature during podding (Experiment 1), and fruit-set at microsporogenesis and flowering at $37^{\circ}$ (Experiment 2 ) and $40^{\circ} \mathrm{C}$ (Experiment 3 ) in groundnut genotypes ${ }^{\mathrm{a}}$

\begin{tabular}{|c|c|c|c|c|c|c|c|}
\hline \multirow[t]{2}{*}{ No. } & \multirow[t]{2}{*}{ Genotype } & \multirow[t]{2}{*}{ RI (\%) } & \multirow[t]{2}{*}{ Soil temperature } & \multicolumn{2}{|c|}{ Microsporogenesis } & \multicolumn{2}{|c|}{ Flowering } \\
\hline & & & & $37^{\circ} \mathrm{C}$ & $40^{\circ} \mathrm{C}$ & $37^{\circ} \mathrm{C}$ & $40^{\circ} \mathrm{C}$ \\
\hline 5 & 796 & 37.9 & 1.28 & 100 & $-{ }^{\mathrm{b}}$ & 0.95 & - \\
\hline 7 & $55-437$ & 48.3 & 0.71 & 100 & 100 & 0.94 & 0.95 \\
\hline 8 & ICG 1236 & 54.9 & 0.99 & 100 & 100 & 0.99 & 0.83 \\
\hline 10 & $47-16$ & 60.4 & 0.71 & 0.89 & 0.25 & 0.87 & 0.19 \\
\hline 3 & ICGS 11 & 64.8 & 0.53 & 0.67 & 0.32 & 0.34 & 0.30 \\
\hline 6 & TMV 2 & 69.7 & 0.57 & 100 & 0.95 & 0.96 & 0.58 \\
\hline 11 & TS32-1 & 78.8 & - & 0.65 & 0.97 & 0.64 & 0.0 \\
\hline 4 & Kadiri 3 & 80.6 & 0.49 & 0.86 & 0.64 & 0.56 & 0.0 \\
\hline 26 & ICGV 93233 & 81.8 & - & - & 0.42 & - & 0.0 \\
\hline 21 & ICGV 93261 & 85.4 & - & - & 0.31 & - & 0.24 \\
\hline 25 & ICGV 92109 & 84.3 & - & - & 0.41 & - & 0.0 \\
\hline 9 & $28-206$ & 84.4 & 0.51 & 0.54 & 0.26 & 0.13 & 0.0 \\
\hline 1 & ICGV 86015 & 85.2 & 0.45 & 0.61 & - & 0.95 & - \\
\hline 16 & ICGV 93269 & 88.3 & - & - & 100 & - & 0.55 \\
\hline 14 & ICGV 93272 & 89.5 & - & - & 0.78 & - & 0.75 \\
\hline 24 & ICGV 93232 & 89.9 & - & - & 0.65 & - & 0.08 \\
\hline 23 & ICGV 93255 & 91.9 & - & - & 0.57 & - & 0.15 \\
\hline 22 & ICGV 92116 & 93.7 & - & - & 0.39 & - & 0.17 \\
\hline 17 & ICGV 93260 & 94.8 & - & - & 0.37 & - & 0.50 \\
\hline 15 & ICGV 92113 & 95.7 & - & - & 0.27 & - & 0.60 \\
\hline 19 & ICGV 92118 & 95.9 & - & - & 0.82 & - & 0.33 \\
\hline 13 & ICGV 92121 & 96.6 & - & - & 0.87 & - & 0.87 \\
\hline 18 & ICGV 92120 & 97.2 & - & - & 0.41 & - & 0.38 \\
\hline 2 & ICGV 86021 & $\mathrm{NM}^{\mathrm{c}}$ & 0.78 & 0.87 & - & 0.87 & - \\
\hline 12 & ICGV 87281 & NM & - & 0.76 & - & 0.74 & - \\
\hline \multirow[t]{2}{*}{20} & ICG 796 & NM & - & - & 0.48 & - & 0.33 \\
\hline & S.E.D. & 6.12 & & & & & \\
\hline
\end{tabular}

${ }^{\text {a }}$ Genotypes in bold are classified as tolerant (ratio $\left.>0.75\right)$ and italics as susceptible (ratio $\left.<0.25\right)$.

${ }^{\mathrm{b}}$ Genotype not included in the experiment.

${ }^{\mathrm{c}}$ RI not measured.

temperature varies among genotypes, as it does in rice (Yoshida et al., 1981), and that some genotypes such as 55-437 and ICG 1236 are more tolerant of the higher temperatures used in 1999 than, for example, genotype 47-16. The response to temperature of fruit-set has been quantified for ICGV 86015 (Prasad et al., 2001): the threshold or critical temperature is $33{ }^{\circ} \mathrm{C}$, the ceiling or maximum temperature is $44^{\circ} \mathrm{C}$, and fruitset is reduced by $5.5 \%{ }^{\circ} \mathrm{C}^{-1}$ between these limits. Values of the critical and ceiling temperature, and sensitivity to temperature, are not available for other genotypes. However, given that temperature responses for developmental events can vary among heat tolerant and susceptible genotypes (Ismail and Hall, 1998), and that there is significant variation among genotypes of groundnut in the response of pollen germination and pollen tube growth to temperature (Kakani et al., in press), as well as in rate of change of HI (Craufurd et al., 2002), there is likely to be genotypic variation in the quantitative response of fruit-set to temperature.

\subsection{Cellular membrane thermostability}

Ismail and Hall (1999), who measured RI in pairs of near isogenic cowpea lines varying in reproductive heat tolerance genes, found lower rates of membrane leakage in heat tolerant lines than in heat susceptible lines. They suggested that RI could be used as a means to screen for heat tolerance in vegetative plants. In this study, there were significant differences between 
genotypes in RI (Table 5). The mean value of RI was $78 \%$, indicating in most genotypes that membrane integrity was damaged by the high temperature treatment of $54{ }^{\circ} \mathrm{C}$ for $15 \mathrm{~min}$. Genotypes 796, ICG 1236 and 55-437 were the most thermo-tolerant with RI values $<60 \%$. Genotypes 47-16, ICGS 11, Kadiri 3 and TS32-1 were moderately tolerant (RI 60-80\%). The remaining genotypes were all more susceptible to heat injury. Srinivasan et al. (1996), who measured RI in 12 genotypes of groundnut, also found genotype ICG 1236 to be the most thermo-tolerant of those studied with a value for RI of $50 \%$. Chauhan and Senboku (1997) found values of RI in six genotypes to vary from 65 to $77 \%$, with TMV 2 having a value for RI of $76 \%$ compared with $68 \%$ in our study.

\subsection{Genotypic variation in heat tolerance}

The responses to high soil and air temperature of all the genotypes tested are summarised in Table 5. Genotypes can be classified as tolerant or susceptible to heat at particular stages of development (e.g. 3 DBF, flowering) or termed as heat resistant based on overall response and maintenance of yield at higher temperatures (Hall, 1992; Mahan et al., 1995). In Table 5 tolerant responses-defined here as having values of CGR (soil temperature) or fruit-set (air temperature) $>75 \%$ of ambient values, are given in bold. Conversely, susceptible responses (in italics) are defined as where values of CGR or fruit-set are $<25 \%$ of ambient values. Genotypes exhibiting tolerant responses in all experiments are defined here as heat resistant.

Genotypes 55-437 and ICG 1236 exhibited tolerant responses in all the three experiments, including the $40{ }^{\circ} \mathrm{C}$ air temperature treatment, as well as having low values of RI. These two genotypes are therefore classed as heat resistant. Genotype $55-437$ is an important cultivar in the Sahelian zone of West Africa known to be well adapted to heat and drought (Greenberg et al., 1992; Ntare et al., 2001). Genotypes 796, ICGV 86021 and ICGV 87281, which were not tested at $40{ }^{\circ} \mathrm{C}$, were nonetheless tolerant to high soil temperature and an air temperature of $37^{\circ} \mathrm{C}$. Genotype 796 also had the lowest value of RI (values of RI were not measured in ICGV 86021 and ICGV 87281). Accordingly, these three genotypes would also be classed as heat resistant. The only other genotype exhibiting tolerance at microsporogenesis (0-6 DBF) and flowering to $40{ }^{\circ} \mathrm{C}$ air temperature was ICGV 92121. The value of RI for this genotype, however, was $96.6 \%$. Likewise, ICGS 11 had a moderately low RI, $64.8 \%$, but was among the most susceptible genotypes to $40{ }^{\circ} \mathrm{C}$ at flowering and microsporogenesis.

Although there was no significant correlation between RI and fruit-set across genotypes in 1999, it does, nonetheless, seem that the most heat resistant genotypes exhibited the greatest degree of membrane integrity $(\mathrm{RI}<60 \%)$ at high temperature. RI may therefore have some potential for screening or prescreening for heat resistance in groundnut. The repeatability of RI values, as well as the potential use of acclimating temperatures prior to boiling (Ismail and Hall, 1999), needs further investigation.

If the heat resistant genotypes do indeed have greater membrane integrity at high temperature (lower values of RI), then it is conceivable that this is translated into higher optimum and maximum temperatures for growth and development processes. Genotypes 55-437 and ICG 1236 do have higher optimum and maximum temperatures for pollen germination and pollen tube growth than the other genotypes (Kakani et al., in press), and this may contribute to greater fruit-set. A greater ability to set fruits at high temperature should increase pod addition rates and sink size, and hence pod, kernel and CGRs (Craufurd et al., 2002). The inheritance of RI and heat tolerance/ susceptibility at these two stages of development is currently being investigated. Molecular/QTL studies of membrane integrity and fruit-set might also help to determine genetic and physiological relationships between these factors.

In the field, heat stress can occur at different stages of crop development and at different intensities and durations. Soil temperatures in excess of $38^{\circ} \mathrm{C}$ are common in semi-arid parts of India and Africa, particularly in crops with sparse stands and where drought is prolonged, and tolerance to high soil temperature should be useful in many circumstances. Flower production is decreased at temperatures greater than $28-30{ }^{\circ} \mathrm{C}$, and previous studies have shown that exposure to air temperatures greater than about $34{ }^{\circ} \mathrm{C}$ during the first part of the day will substantially reduce fruit-set when these temperatures coincide with microsporogenesis and flowering (Prasad et al., 1999a). Heat resistant genotypes should be beneficial under these circumstances. However, as well as tolerance of individual organs or 
tissues to heat, 'escape' at the whole plant level is also important. In the field many floral buds and flowers may avoid the deleterious effects of high air temperature; in groundnut, flowers are borne at the base of the plant, either within the canopy or in the soil, and so may experience a different microclimate to the foliage above. Groundnuts are also botanically indeterminate and flowers are borne on inflorescences, allowing temporal escape and recovery. Furthermore, pollination and fertilisation may occur early in the morning in some genotypes before air temperature reaches the critical level—another type of escape.

\section{Conclusions}

It was striking that a number of genotypes were consistently tolerant to high temperature, whether air or soil, and whether measured in terms of CGR, fruitset or membrane thermostability. It is quite clear that 55-437 and ICG 1236, and probably 796, ICGV 86021, ICGV 87281 (all Spanish types) and ICGV 92121 (Virginia bunch), are heat resistant, and that this resistance is apparently not limited to a specific stage of development or process. Furthermore, these genotypes are of diverse origin, indicating potentially different sources of resistance. Reproductive heat tolerance at microsporogenesis and flowering can be screened for by recording the fruit-set of flowers exposed to high air temperature for 1 day at the respective stage of development.

\section{Acknowledgements}

We thank ICRISAT Centre for providing seed and Mr. K. Chivers and Mrs. C. Hadley for excellent engineering and technical support.

\section{References}

Bhagsari, A.S., Brown, R.H., Schepers, J.S., 1976. Effect of moisture stress on the photosynthesis and some related physiological characteristics in peanut. Crop Sci. 16, 712-715.

Chauhan, Y.S., Senboku, T., 1997. Evaluation of groundnut genotypes for heat tolerance. Ann. Appl. Biol. 131, 481-489.

Cox, F.R., 1979. Effect of temperature on peanut vegetative and reproductive growth. Peanut Sci. 6, 14-17.
Craufurd, P.Q., Wheeler, T.R., Ellis, R.H., Summerfield, R.J., Prasad, P.V.V., 2000. Escape and tolerance to high temperature at flowering in groundnut (Arachis hypogaea L.). J. Agric. Sci. (Camb.) 135, 371-378.

Craufurd, P.Q., Prasad, P.V.V., Summerfield, R.J., 2002. Dry matter production and rate of change of harvest index at high temperature in peanut. Crop Sci. 42, 146-151.

Duncan, W.G., McCloud, D.E., McGraw, R.L., Boote, K.J., 1978. Physiological aspects of peanut yield improvement. Crop Sci. $18,1015-1020$.

FAO, 2001. Production Year Book 2000. Food and Agricultural Organization, Rome, Italy.

Genstat 5 Committee, 1987. Genstat 5 Reference Manual. Clarendon Press, Oxford, UK.

Golombek, S.D., Johansen, C., 1997. Effect of soil temperature on vegetative and reproductive growth and development in three Spanish genotypes of peanut (Arachis hypogaea L.). Peanut Sci. 24, 67-72.

Greenberg, D.C., Williams, J.H., Ndunguru, B.J., 1992. Differences in yield determining processes of peanut (Arachis hypogaea) genotypes in varied drought environments. Ann. Appl. Biol. 120, 557-566.

Gross, Y., Kigel, J., 1994. Differential sensitivity to high temperature of stages of the reproductive development of common bean (Phaseolus vulgaris L.). Field Crops Res. 36, 201-212.

Hall, A.E., 1992. Breeding for heat tolerance. Plant Breed. Rev. 10, 129-167.

Hall, A.E., 1993. Physiology and breeding for heat tolerance in cowpea, and comparisons with other crops. In: Kuo, C.G. (Ed.), Adaptation of Food Crops to Temperature and Water Stress. Asian Vegetable Research and Development Center, Taipei, Taiwan, pp. 271-284.

Houghton, J.T., Ding, Y., Griggs, D.J., Noguer, M., van der Linden, P.J., Xiaosu D. (Eds.), 2001. Climate Change 2001: The Scientific Basis. Contribution of Working Group I to the Third Assessment Report of the Intergovernmental Panel on Climate Change (IPCC). Cambridge University Press, UK, p. 944.

ICRISAT, 1994. ICRISAT West Africa Programs Annual Report, 1993. ICRISAT Sahelian Centre, Niamey, Niger, pp. 36-37.

Ismail, A.M., Hall, A.E., 1998. Positive and potential negative effects of heat-tolerance genes in cowpea. Crop Sci. 38, 381390.

Ismail, A.M., Hall, A.E., 1999. Reproductive-stage heat tolerance, leaf membrane thermostability and plant morphology in cowpea. Crop Sci. 39, 1762-1768.

Kakani, V.G., Prasad, P.V.V., Craufurd, P.Q., Wheeler, T.R.W., in press. Response of in vitro pollen germination and pollen tube growth of groundnut (Arachis hypogaea L.) genotypes to temperature. Plant Cell Environ.

Kishinevsky, B.D., Sen, D., Weaver, R.W., 1992. Effect of high root temperature on Bradyrhizobium-peanut symbiosis. Plant Soil $143,275-282$.

Mahan, J.R., McMichael, B.L., Wanjura, D.F., 1995. Methods for reducing the adverse effects of temperature stress on plants: a review. Environ. Exp. Bot. 35, 251-258. 
Martineau, J.R., Specht, J.E., Williams, J.H., Sullivan, C.Y., 1979. Temperature tolerance in soybeans. 1. Evaluation of technique for assessing cellular membrane thermostability. Crop Sci. 19, 75-78.

Matthews, R.B., Horie, T., Kropff, M.J., Bachelet, D., Centeno, H.G., Shin, J., Mohandass, S., Singh, S., Defeng, Z., Lee, M.H., 1995. A regional evaluation of the effect of future climate change on rice production in Asia. In: Modeling the Impact of Climate Change on Rice Production in Asia. CAB International, Wallingford, pp. 95-139.

Ntare, B.R., Williams, J.H., Dougbedji, F., 2001. Evaluation of groundnut genotypes for heat tolerance under field conditions in a Sahelian environment using a simple physiological model for yield. J. Agric. Sci. (Camb.) 136, 81-88.

Prasad, P.V.V., Craufurd, P.Q., Summerfield, R.J., 1999a. Fruit number in relation to pollen production and viability in groundnut exposed to short episodes of heat stress. Ann. Bot. (Lond.) 84, 381-386.

Prasad, P.V.V., Craufurd, P.Q., Summerfield, R.J., 1999b. Sensitivity of peanut to timing of heat stress during reproductive development. Crop Sci. 39, 1352-1357.

Prasad, P.V.V., Craufurd, P.Q., Summerfield, R.J., 2000a. Effect of high air and soil temperature on dry matter production, pod yield and yield components of groundnut. Plant Soil 222, 231-239.

Prasad, P.V.V., Craufurd, P.Q., Summerfield, R.J., Wheeler, T.R., 2000b. Effects of short episodes of heat stress on flower production and fruit-set in groundnut (Arachis hypogaea L.). J. Exp. Bot. 345, 777-784.

Prasad, P.V.V., Craufurd, P.Q., Kakani, V.G., Wheeler, T.R., Boote, K.J., 2001. Influence of temperature during pre- and postanthesis stages of floral development on fruit-set and pollen germination in groundnut (Arachis hypogaea L.). Aust. J. Plant Physiol. 28, 233-240.

SAS Institute, 1996. SAS Users Guide. SAS Institute, Cary, NC, USA.

Srinivasan, A., Takeda, H., Senboku, T., 1996. Heat tolerance in food legumes as evaluated by cell membrane thermostability and chlorophyll fluorescence techniques. Euphytica 88, 35-45.

Talwar, H.S., Yanagihara, S., 1999. Physiological basis for heat tolerance during flowering and pod setting stages in groundnut (Arachis hypogaea L.). JIRCAS Working Report No. 14. JIRCAS, Okinawa, Japan, pp. 47-65.

Talwar, H.S., Takeda, H., Yashima, S., Senboku, T., 1999. Growth and photosynthesis responses of groundnut genotypes to high temperature. Crop Sci. 39, 460-466.

Vara Prasad, P.V., Craufurd, P.Q., Summerfield, R.J., 2001. Response of groundnut dependent on symbiotic and inorganic nitrogen to high soil and air temperatures. J. Plant Nutr. 24, 623-637.

Wheeler, T.R., Chatzialioglou, A., Craufurd, P.Q., Ellis, R.H., Summerfield, R.J., 1997. Dry matter partitioning in peanut exposed to high temperature stress. Crop Sci. 37, 1507-1513.

Wheeler, T.R., Craufurd, P.Q., Ellis, R.H., Porter, J.R., Prasad, P.V.V., 2000. Temperature variability and the yield of annual crops. Agric. Ecosyst. Environ. 82, 159-167.

Williams, J.H., Boote, K.J., 1995. Physiology and modellingpredicting the unpredictable legume. In: Pattee, H.E., Stalker, H.T. (Eds.), Advances in Peanut Science. American Peanut Research and Education Society, Stilwater, OK, USA, pp. 301-353.

Yoshida, S., Satake, J., MacKill, D.J., 1981. High-temperature stress in rice. IRRI Research Paper Series 67. International Rice Research Institute, Manila, Philippines. 